\title{
Financial, Environmental and Energy Analysis of Various Micro-CHP Systems within the UK Domestic Market
}

\author{
T. S. Doyle, Z. Dehouche, A. Harries, and I. Rizos
}

\begin{abstract}
Widespread uptake of decentralized energy production has the potential to reduce carbon emissions whilst making the energy market more affordable, sustainable and robust. The application of micro-CHP systems in the domestic market has the potential to alleviate pressure on the national grid by displacing electrical and heating demands, and also through the export of excess electricity. Initial market support for this has been shown by the UK's Feed-in-tariff scheme which is currently incentivizing efficient micro-CHP systems $(<2 \mathrm{~kW})$ by providing a financial return for every unit of electrical energy produced and further reward for every unit exported to the grid. It is the aim of this research to attempt to identify those m-CHP systems available on the market and to quantify the expected benefits in terms of cost, $\mathrm{CO}_{2}$ savings and overall energy efficiency when feeding a typical domestic property in the UK.In an attempt to maximize financial income from the FIT scheme an operating strategy of constant supply, at the maximum rated output, is compared against the conventional heat led approach most often used in CHP applications. Overall results indicate that the heat-to-power ratio for a given $\mathrm{m}$-CHP has a direct impact on all of the performance factors being measured and also determines the preferred operating strategy that should be followed.
\end{abstract}

Index Terms-Distributed generation, energy efficiency, feed-in-tariff, m-CHP.

\section{INTRODUCTION}

Combined heat and power (CHP) systems are designed to utilize the useful heat and electrical energy produced from a single source,and near the point of use. Environmental and economical benefits are a result of reduced fuel consumption and emissions whilst increasing overall energy efficiency. Considering existing centralized energy plants lose two thirds of their energy to the atmosphere, in the form of heat, along with further losses caused by distribution. The advantages of distributed power generation in small decentralized units are becoming ever more apparent. The implementation of CHP systems is actively being promoted in Europe through the Cogeneration Directive 2004/08/EC where the initial objectives were to deliver primary energy savings but has grown in importance as the climate agenda has become more of a concern. By reducing the scale of these systems $(\sim 2 \mathrm{kWe})$ these micro-CHP appliances can be installed at the point of use within a domestic environment and can be fuelled by conventional natural gas supplies. Producing onsite

Manuscript received October 25, 2012; revised December 28, 2012. This work was supported by the EngDprogramme at Brunel University and sponsored by the EPSRC and BDSP Partnership.

T. S. Doyle and Z. Dehouche are with the School of Engineering and Design at Brunel University, Uxbridge, Middlesex, UK (e-mail: tygue.doyle@brunel.ac.uk; zahir.dehouche@brunel .ac.uk). UK. electricity means centrally generated electricity is displaced and by utilizing the heat produced to supply domestic hot water and space heating demands further savings in overall gas consumption can be made.

In order for us to fully understand the benefits of such systems it is important to explore the environmental and economic factors that will decide their commercial success. In recognition of the potential to reduce carbon emissions attributed to the households the UK government is supporting the uptake of $\mathrm{m}-\mathrm{CHP}(<2 \mathrm{~kW})$ through the national feed-in-tariff (FIT) scheme which is due to be increased from $11 \mathrm{p} / \mathrm{kWh}$ to $12.5 \mathrm{p} / \mathrm{kWh}$ [1] (at time when all other tariffs are being reduced). The common technologies used in the category of m-CHP are; internal combustion engines (ICE), Stirling engines, organic Rankine cycle and fuel cells. Table I illustrates the various products currently available in the sub-2kW m-CHP market.

Due to their high electrical efficiencies, low noise and gas emissions fuel cells are a very attractive option as residential $\mathrm{m}$-CHP systems. There is now a high temperaturefuel cell unit that is commercially available and is accredited under the UK's Micro Generation Scheme (MCS) making this product eligible for the UK feed-in-tariff. This elevates the status of this technology out of the stage of research and development and now faces the challenges associated with new technologies entering into the market.

\section{Methodology}

This paper will look to evaluate the performance of the products specified in Table I whilst supplying a load which is representative of a typical home found in the UK. Electrical and domestic hot water (DHW) loads were obtained from a study carried out by the International Energy Agency Energy Conservation in Buildings and Community Systems (ECBCS) under the title COGEN-SIM and published results are presented in Annex 42 [2]. The electrical demand profile from the study was obtained from actual readings of a $65 \mathrm{~m}^{2}$ home in Newcastle. The DHW profile represents a 200 1/day consumption rate where values have been obtained from probability functions with the assumption that the temperature of the water is increased by $35^{\circ} \mathrm{C}$ relative to the inlet feed temperature. Space heating demands have been generated through thermal modelling using TAS software developed by Environmental Design Solutions Limited [3]. In order to represent a building similar to that of the property monitored in Newcastle u-values representing pre-1980 domestic constructions were obtained from the National Calculation Method (NCM) as defined by the Department for Communities and Local Government which provides a database of constructions and services for evaluating the 
performance of a building's energy consumption. Building layouts were obtained using information published by the Energy Savings Trust [4], [5] and a floor plan of a typical semi-detached house was used. See Table II for a summary of the constructions used for the various building elements and the subsequent thermal properties calculated by the software.

TABLE I: MARKET SUMMARY OF AVAILABLE M-CHP SySTEMS WITH THEIR RESPECTIVE PERFORMANCE VALUES

\begin{tabular}{|c|c|c|c|c|c|c|}
\hline Brand & Product & Technology & Electrical output kW(eff) & Thermal output kW(eff) & Overall efficiency & Fuel \\
\hline Whisper Tech Limited & WhisperGen & Stirling engine & $1.2(12 \%)$ & $12(78 \%)$ & $90 \%$ & NG \\
\hline Stirling systems & SEM & Stirling engine & $1.2(18 \%)$ & $5(72 \%)$ & $90 \%$ & NG \\
\hline Baxi & Ecogen & Stirling engine & $1.1(9 \%)$ & $24(83 \%)$ & $92 \%$ & NG \\
\hline Baxi & Innotech & PEMFC & $1(32 \%)$ & $1.8(59 \%)$ & $91 \%$ & NG \\
\hline Otag & Lion-powerblock & Rankine engine & $2(12 \%)$ & $16(73 \%)$ & $85 \%$ & NG \\
\hline EnergetixGenlec & Kingston & Rankine engine & $1(12 \%)$ & $6.8(78 \%)$ & $90 \%$ & NG, LPG \\
\hline Climate Energy & freewatt (Honda) & ICE & $1.2(26 \%)$ & $2.7(59 \%)$ & $85 \%$ & NG, LPG \\
\hline Valliant & EcoPOWER (Honda) & ICE & $1(26 \%)$ & $2.5(66 \%)$ & $92 \%$ & NG, LPG \\
\hline CFCL & Bluegen & SOFC & $1.5(60 \%)$ & $0.54(25 \%)$ & $85 \%$ & NG \\
\hline \multicolumn{5}{|c|}{ Natural Gas (NG), Liquid Petroleum Gas (LPG) } & & \\
\hline
\end{tabular}

TABLE II: DESCRIPTION OF CONSTRUCTION LAYERS AND MATERIALS APPLIED TO VARIOUS BUILDING ELEMENTS FOR THERMAL MODELLING

\begin{tabular}{|c|c|c|}
\hline Building Element & Construction layers and materials & u-value $\left(\mathrm{W} / \mathrm{m}^{2} .{ }^{\circ} \mathrm{C}\right)$ \\
\hline Ground floor & $50 \mathrm{~mm}$ flooring screed, $10 \mathrm{~mm}$ insulation, $100 \mathrm{~mm}$ concrete, $25 \mathrm{~mm}$ brick slips, underfloor clay & 0.849 \\
\hline External wall & $102 \mathrm{~mm}$ brick, $50 \mathrm{~mm}$ air layer, $100 \mathrm{~mm}$ brick, $13 \mathrm{~mm}$ dense plaster & 1.287 \\
\hline Internal wall & $100 \mathrm{~mm}$ concrete block, $25 \mathrm{~mm}$ air layer, $60 \mathrm{~mm}$ insulation, $13 \mathrm{~mm}$ plasterboard & 0.821 \\
\hline Pitched roof & $9.5 \mathrm{~mm}$ plasterboard, $200 \mathrm{~mm}$ insulation, $1 \mathrm{~m}$ loft space, $10 \mathrm{~mm}$ concrete tiles & 0.178 \\
\hline Suspended floor & $30 \mathrm{~mm}$ plywood, $20 \mathrm{~mm}$ insulation, $35 \mathrm{~mm}$ air layer, $100 \mathrm{~mm}$ concrete & 0.532 \\
\hline PVC double glazing & PVC frame with two hollow chambers, $4 \mathrm{~mm}$ clear glass, $6 \mathrm{~mm}$ air layer, $4 \mathrm{~mm}$ clear glass & 3.297 \\
\hline External door & $9 \mathrm{~mm}$ plywood, $25 \mathrm{~mm}$ insulation, $9 \mathrm{~mm}$ plywood & 0.755 \\
\hline
\end{tabular}

Annual UK energy demand profiles for single domestic property

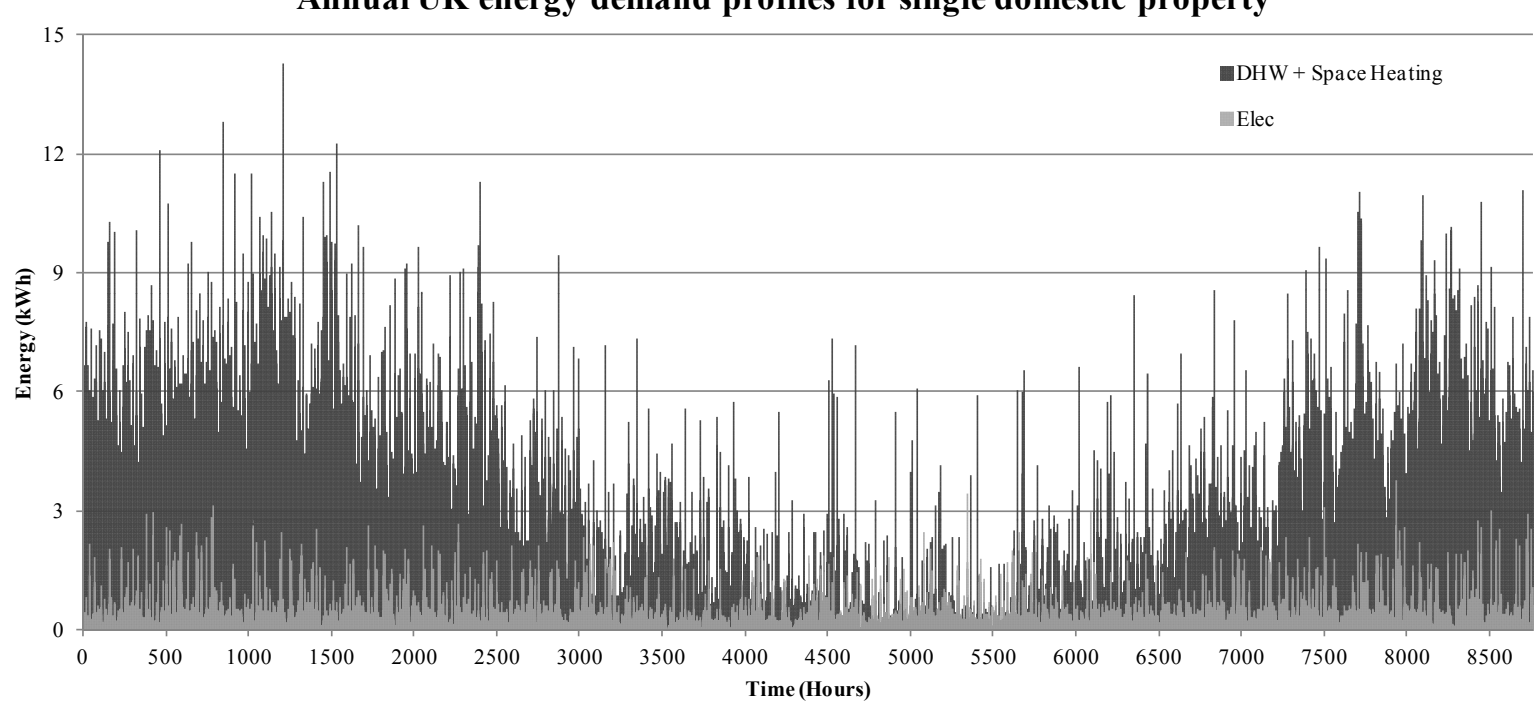

Fig. 1. The graph represents the annual fluctuations in the heating demand, comprising of the DHW and space heating requirements, as well as the electrical demand for an average domestic property in the UK with a total annual heating demand of $16,406 \mathrm{kWh}$ and electrical demand of $3028 \mathrm{kWh}$.

Fig. 1 illustrates the annual heating and electrical demand profile for a typical domestic property in the UK. The annual electrical consumption stands at $3,028 \mathrm{kWh}$ and the heating demand, divided into DHW and space heating stands at $2,980 \mathrm{kWh}$ and $13,425 \mathrm{kWh}$ respectively, and in terms of the property the annual contribution from each is $69 \%$ towards space heating and $16 \%$ and $15 \%$ for electrical and DHW respectively. These values are consistent with UK's gas and electricity regulator Ofgem who use typical medium consumption figures of $3,300 \mathrm{kWh}$ and $16,500 \mathrm{kWh}$ for electricity and gas respectively [6].

The main objective of this study is to compare the energy, financial and environmental performance of a home with and without the application of a m-CHP system and how incentives such as the UK's FIT scheme can contribute to their widespread uptake.

To do this successfully the performance of this typical home must be identified according to the standard grid efficiency, unit price per $\mathrm{kWh}$ for electricity and gas and $\mathrm{CO}_{2}$ emission factors associated with the consumption of both 
electricity and gas. For a summary of these values please refer to Table III. According to information published by the UK's Department of Energy and Climate Change (DECC) the total primary energy (including renewables) used for the production of electricity in 2012 for the UK was 901.3TWh and the total amount of electricity delivered to the consumer was $320.5 \mathrm{TWh}$ [7]. This amounts to an overall efficiency of $35.6 \%$ for the electricity supplied from the grid.

\section{RESUlTS AND Discussion}

With this hourly energy information for the building we can begin to analyze the performance of the building and we shall begin by applying the variables set out in Table III to describe the financial, environmental and energy performance for the given loads.

TABLE III: INFORMATION DESCRIBING THE COST AND PERFORMANCE OF THE UK NATION GRID

\begin{tabular}{|l|l|}
\hline UK Grid & \multicolumn{2}{|l|}{} \\
\hline Electrical Efficiency $(\%)$ & 35.6 \\
\hline Average boiler efficiency $(\%)$ & $79 \quad[8][9]$ \\
\hline Unit cost for electricity $(\mathrm{p} / \mathrm{kWh})$ & $12.79 \quad[10]$ \\
\hline Unit cost for gas $(\mathrm{p} / \mathrm{kWh})$ & $4.05 \quad[11]$ \\
\hline $\mathrm{CO}_{2}$ factor for electricity $\left(\mathrm{kgCO}_{2} / \mathrm{kWh}\right)$ & $0.5246 \quad[12]$ \\
\hline $\mathrm{CO}_{2}$ factor for gas $(\mathrm{kgCO} / \mathrm{kWh})$ & $0.1836 \quad[12]$ \\
\hline $\mathrm{Gross}$ calorific value for $n$ atural gas $(\mathrm{MJ} / \mathrm{m} 3)$ & $39.4 \quad[13]$ \\
\hline UK Feed-in-tariff scheme for m-CHP $(<2 \mathrm{~kW})$ & \multicolumn{2}{|l|}{} \\
\hline Generation $(\mathrm{p} / \mathrm{kWh})$ & 12.5 \\
\hline Export $(\mathrm{p} / \mathrm{kWh})$ & 4.5 \\
\hline
\end{tabular}

In comparison we must understand how the m-CHP systems described in Table I will influence the values expressed in Table IV. For this comparison we assume all excess electricity is exported to the grid and excess heat is stored in a hot water storage tank which incurs a heat loss of $10 \%$ per hour. The m-CHP system will be installed along with the existing boiler that will be used to cope with any demand that cannot be met by the m-CHP and hot water storage tank, and similarly electricity will be imported to make up for any shortfall in electrical supply. Also, to be considered is the operating strategy of the m-CHP unit as conventional CHP systems are heat led but systems such as the high temperature fuel cell are required to run at a constant supply. So for the purpose of this analysis one representative technology from the above systems will be operated at constant supply and as a comparison will also operate as conventional heat led systems which will give us an opportunity to evaluate the best strategy to adopt in terms of financial payback using the FIT scheme, environmental $\mathrm{CO}_{2}$ emissions and overall system efficiency.

TABLE IV: RESULTING ENERGY BILL, $\mathrm{CO}_{2}$ EMISSIONS AND SYSTEM EFFICIENCY FOR A TYPICAL UK HOME

\begin{tabular}{|l|l|l|l|}
\hline & Energy bill & Total $\mathrm{CO}_{2}$ emissions & System Efficiency \\
\hline Electricity & $£ 387$ & $1,589 \mathrm{~kg}$ & $35.6 \%$ \\
\hline Gas & $£ 841$ & $3,012 \mathrm{~kg}$ & $79.0 \%$ \\
\hline Overall & $£ 1,228$ & $4,601 \mathrm{~kg}$ & $72.2 \%$ \\
\hline
\end{tabular}

\section{A. Whispergen}

It is clear to see that the m-CHP systems with high heat-to-power ratios such as the Stirling engine based Whispergen are far better off operating under the heat led strategy. In terms of meeting the demand and efficiency, illustrated in Fig. 2 a) and b), the heat led strategy enables the unit to meet $99 \%$ of the building's heat demand but only $44 \%$ of the electrical and allows the unit to maintain a high level of efficiency with the total household efficiency, including imported backup electricity and gas, standing at $85 \%$, as seen in Table V. This is supported by the financial analysis, shown in Fig. 2 c) and d) which shows that when the Whipsergen is heat led the total grid cost is constantly below the cost expected without the $\mathrm{m}-\mathrm{CHP}$ unit which will provide an annual financial saving of $43 \%$ and an overall $\mathrm{CO}_{2}$ saving of $16 \%$. During constant supply the unit generates a large amount of heat that cannot be utilized by the building and therefore has a detrimental effect on the system efficiency and operating cost of the unit.

\section{B. ECOPOWER}

The reduced heat-to-power ratio of the ICE EcoPower unit shows a smaller performance gap between heat led and constant operation strategy, seen in Fig. 3 a) and b), and the decision on which strategy is most suitable is not clear as the heat led strategy meets only $63 \%$ and $60 \%$ of the heating and electrical load whilst the constant supply strategy supplies $79 \%$ and $91 \%$ of the heating and electrical requirements. Also, operating at constant supply the unit indicates a greater financial saving of $83 \%$ compared to $60 \%$ for the heat led, and the $\mathrm{CO}_{2}$ savings marginally favor the heat led strategy with a $21 \%$ saving compared to $15 \%$ for the constant supply. So environmentally the heat led strategy is best but if cost is the main driver the constant supply would be favored, it is important to mention that these financial benefits are due to the FIT and that without the FIT the heat led strategy would be the best strategy to adopt, as illustrated in Fig. 3 c) and d).

TABLE V: RESUlTING ENERGY BILL, $\mathrm{CO}_{2}$ SAVINGS AND EFFICIENCY FOR A TYPICAL UK HOME

\begin{tabular}{|c|c|c|c|c|c|}
\hline & \multicolumn{2}{|c|}{ Whispergen } & \multicolumn{2}{|c|}{ EcoPOWER } & \multirow{2}{*}{$\begin{array}{l}\text { Bluegen } \\
\text { Constant }\end{array}$} \\
\hline & Heat led & Constant & Heat led & Constant & \\
\hline Gas cost (m-CHP) & $£ 842$ & $£ 3,546$ & $£ 637$ & $£ 1,364$ & $£ 886$ \\
\hline FIT - generation & $\underline{£ \quad 312}$ & $£ 1,314$ & $\underline{£ \quad 511}$ & $\underline{£ 1,095}$ & $£ 1,643$ \\
\hline FIT - export & $£ 52$ & $\underline{£ 345}$ & $\underline{£ 103}$ & $\underline{£ 270}$ & $\underline{£ 460}$ \\
\hline Grid import (Gas\&Elec) & $£ 226$ & $£ 25$ & $£ 465$ & $£ 213$ & $£ 618$ \\
\hline Total cost/income & $£ 703$ & $£ 1,911$ & $£ 487$ & $£ 212$ & $\underline{£ 598}$ \\
\hline $\mathrm{CO}_{2}$ savings & $16 \%$ & $-74 \%$ & $21 \%$ & $15 \%$ & $36 \%$ \\
\hline Overall household efficiency & $85 \%$ & $31 \%$ & $83 \%$ & $61 \%$ & $78 \%$ \\
\hline
\end{tabular}

Underlined values indicate income rather than expense. Constant indicates the unit operates continually at the maximum rated output. 


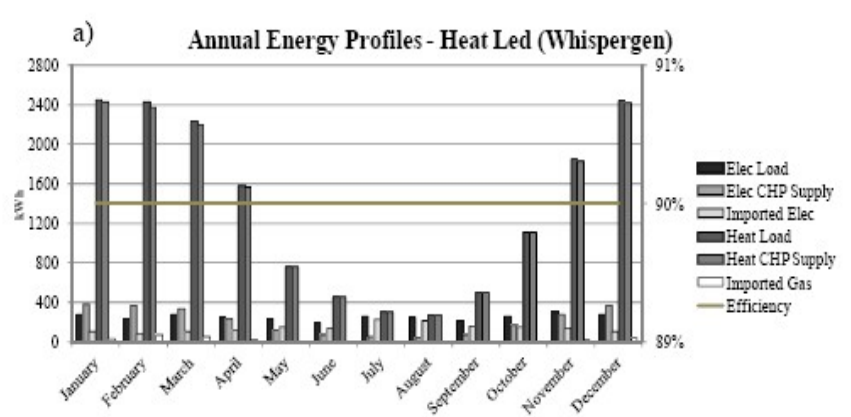

b) Annual Energy Profiles - Constant Supply (Whispergen)

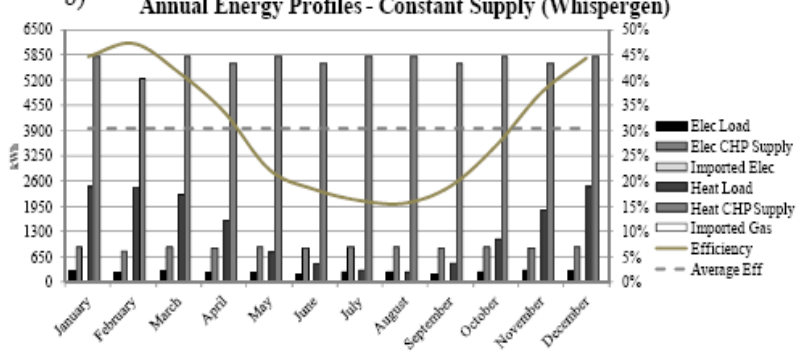

Annual Costs/Savings - Heat Led (Annual Expense with

c)

Whispergen $£ 703$ )
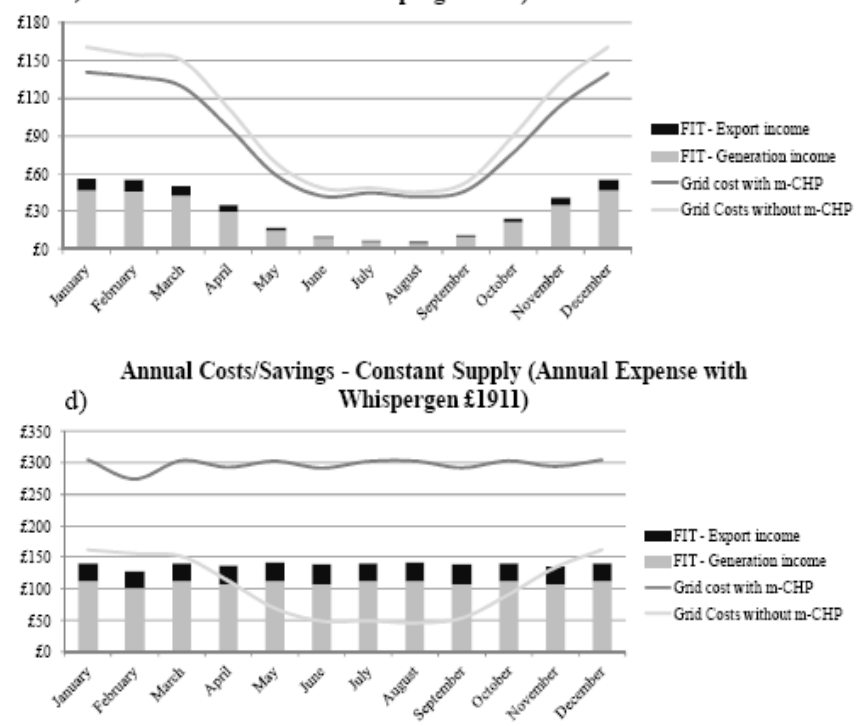

Fig. 2. Graphs a) and b) illustrate the monthly quantities of demand and supply of the home and Whispergenas well excess energy imported to meet peak demands outside of the m-CHP's rated capacity, the overall monthly system efficiency is also plotted. Graphs c) and d) represent the financial incomes and expenses according to the unit cost of gas and electricity and the UK's FIT scheme with and without the m-CHP.

\section{A. Bluegen}

The high temperature fuel cell Bluegen unit offers the lowest heat-to-power ratio of all the technologies tested and the results in Fig 4 a) indicate a very high level of efficiency throughout the year with an expected drop in the summer where there is insufficient demand for the heat produced. The constant supply of heat only satisfies $28 \%$ of the heating demand, which is why an installation of this kind would require a secondary gas boiler or an electric immersion heater providing further heating to the hot water storage tank whilst utilizing the m-CHP's constant electrical output. The unit satisfies $97 \%$ of the annual electrical demand and benefits greatly from the FIT scheme as the unit will provide an annual income of $£ 598$ which equates to a financial saving of $149 \%$, again this is solely due to the FIT and if we study the grid cost lines in Fig 4 b) it can be seen that without the FIT the unit would cost more to run compared to the existing grid connection. Therefore for this system to be commercially competitive a long term tariff will be required for the power produced and/or there will need to be an increase in the grid price for electricity. Along with the substantial financial savings Bluegen unit will also provide a $\mathrm{CO}_{2}$ saving of $36 \%$ and an overall household efficiency of $78 \%$.
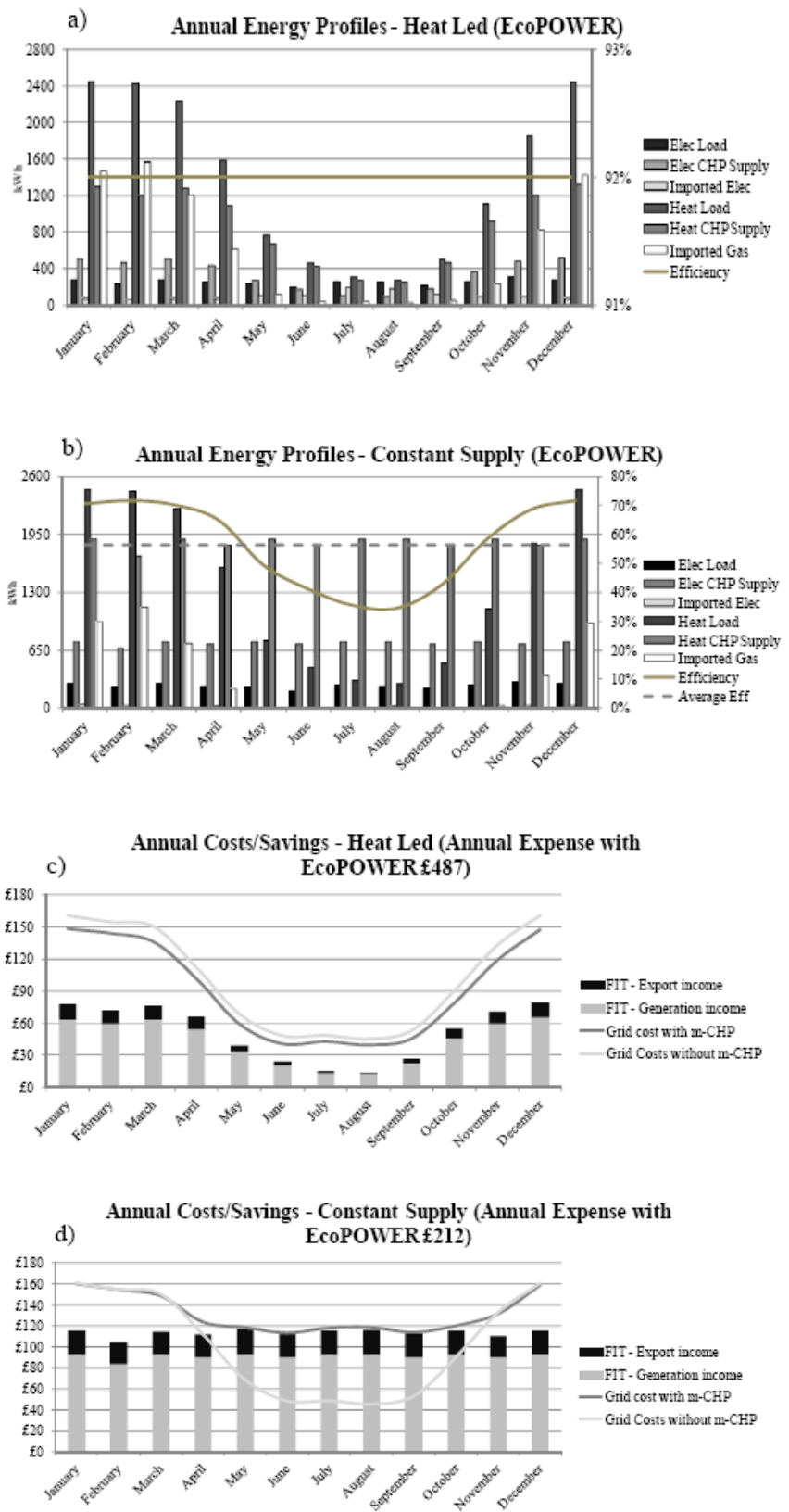

Fig 3. Similar to the Whispergen graphs of the EcoPOWER unit displays higher operating efficiency during both heat led and constant supply operating strategy seen in a) and b). This benefit also influences the financial cost of the unit as seen in c) and d) both values are lower than the Whispergen with the constant supply being the most cost effective, although not without the support of the FIT.

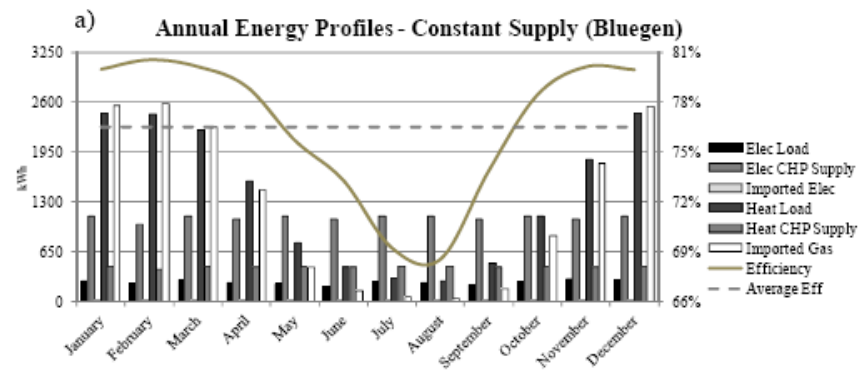




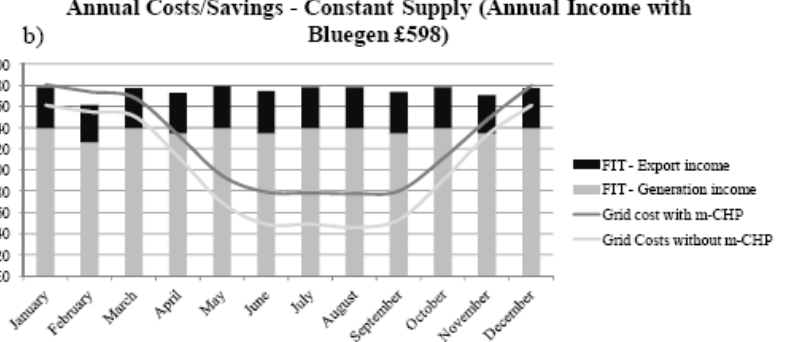

Fig. 3. The high temperature fuel cell is only measured under constant supply as this is the standard operating procedure used in order to protect the lifespan of the unit. The surplus heat generated over the summer months clearly has an effect on the operating efficiencies and is clearly illustrated in a). In b) we can see the benefit of the increased electrical capacity which results in a financial income owing to the UK's FIT.

\section{CONCLUSIONS}

The factors influencing the feasibility of the m-CHP system studied have shown to be the heat-to-power ratio as this has a direct influence on the optimal operating strategy. It can be seen that those m-CHP units with high heat-to-power ratios benefit from being heat led as operating costs are reduced, even before accounting for the financial income generated through the FIT, and $\mathrm{CO}_{2}$ savings are far greater compared to being run at constant supply. Reducing the heat-to-power ratio has shown to have similar cost savings when run as heat led but whenincluding savings generated through the FIT, because more electricity is being produced, overall costs are further reduced. The high temperature fuel cell with its much lower heat-to-power ratio is the only unit which sees a positive income for the year and because of the reduced amount of heat produced can successfully be run at constant supply resulting in the unit constantly generating income. It is also interesting to note that the percentage of $\mathrm{CO}_{2}$ savings steadily increases with reduced heat-to-power ratio. This can be attributed to the difference in grid supplied electrical efficiency and heat supplied by a supplement boiler which in this study operates with a 79\% efficiency.By minimizing the heat generated over the summer period with a low heat-to-power ratio losses can be reduced whilst allowing the m-CHP unit to operate at constant supply.

\section{REFERENCES}

[1] Providing certainty for Feed-in Tariffs and the Renewable Heat Incentiive. [Online]. Available: http://www.decc.gov.uk/en/content/cms/news/pn12_085/pn12_085.as px.

[2] The ECBCS Research Programme. [Online]. Available: http://www.ecbcs.org/annexes/index.htm.

[3] Environmental Design Solution (EDSL). (2012). [Online]. Available: http://www.edsl.net.

[4] Energy Saving Trust. (2010). EST House types comparison complete set ${ }^{\star}$. [Online]. Available: http://www.energysavingtrust.org.uk/

[5] Energy Saving Trust. (2010). Fabric first -Focus on fabric and services performance to increase energy performance in new homes. [Online] Available: http://www.energysavingtrust.org.uk/

[6] Typical domestic energy consumption figures - Factsheet 96', Ofgem, January 2011.

[7] I. M. Leay, K. Harris, and A. Annut, "Digest of United Kingdom Energy Statistics 2012," Department of Energy and Climate Change. National Statistics, 2012.

[8] Energy Saving Trust. (2012). Saving assumptions for the Free lunch project. [Online]. Available: http://www.energysavingtrust.org.uk/

[9] E. Hogg, "Committee on Climate Change, MAC Curves for the Domestic and Non-Domestic Building Sectors," Technical Documentation, 2012.
[10] Quarterly energy prices table 5.5.1: Domestic electricity prices in the EU and $G 7$ countries, DECC Publication, September 2012.

[11] Quarterly energy prices table 5.9.1: Domestic gas prices in the EU and G7 countries, DECC Publication, September 2012.

[12] Conversion factors - Energy and carbon conversions 2011 update, Carbon Trust, 2011.

[13] Carbon Emission Factors and Calorific Values from the UK Greenhouse Gas Inventory (AEA, 2011) to Support the EU ETS, DECC Publication, April 2011.

[14] Feed-in Tariff scheme: Tariff Table 1 December 2012 - 31 March 2013 Non-PV Only, Ofgem, October 2012.

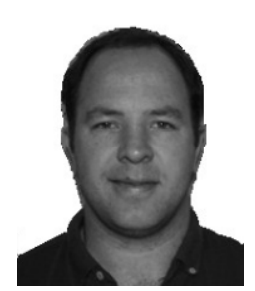

Tygue S. Doyle is originally from South Africa, obtained a first class BEng degree in mechanical engineering at Brunel University, London, UK. From which he gained a sound understanding of thermofluids, material design and manufacturing, project management, the application of numerical modelling, simulation and computer graphics.

$\mathrm{He}$ is now a Research Engineer at BDSP Partnership where he is completing an Engineering Doctorate and leads the Fuel Cell and Waste to Energy research area in the BDSP Renewable Energy Group. He is currently developing full process mathematical models of gasification plants with a fuel cell combined-cycle and numerical models of specific components in order to maximize electrical energy conversion efficiencies.

Mr. Doyle is a member of IMechE, The Electrochemical Society and ASME. He is also the founding member of the Mechanical Engineering Society at Brunel University.

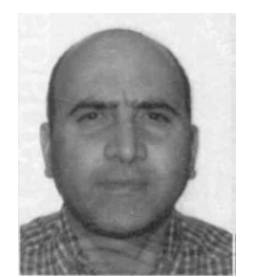

Zahir Dehouche holds MSc and PhD degrees from Claude Bernard University, Lyon, France: his PhD topic was part of the EU Major Industrial Hazards Research Programme dealing with mitigation of accidental releases of hazardous gases.

$\mathrm{He}$ is a Lecturer and MSc Course Director of Sustainable Energy Technologies and Management at Brunel University. Post-doctoral research (Institut Für Kernenergetik und Energiesysteme (IKE) of University of Stuttgart (1994/5) Germany) was followed by 10 years as a research fellow (Hydrogen Research Institute (HRI) at University of Québec, Canada) and 3 years as a senior research officer at Laval University, Québec (2005-2008).

Dr. Dehouche has authored over 100 interdisciplinary journal and conference papers, besides reports and two patents being applied for. He is an Editorial Board Member of Open Nanoscience Journal and a member of the American Nano-Society. He is co-author of New Nanotechnology Research, Novapublishers, 2006

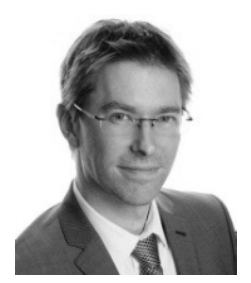

Alan Harries obtained a first class process engineering degree at Aston University in Birmingham, UK, winning the 'First in Year' award and went on to complete a $\mathrm{PhD}$ in the computer simulation of complex fluid flow and heat transfer.

$\mathrm{He}$ is now is an Associate Partner at Smiths Gore and manages the renewable energy and sustainability consultancy in the Midlands and South England. He is currently leading renewable energy project for clients such as Crown Estate and the Church Commissioners for England. He was previously a Senior Environmental Consultant and Team Leader of the Renewable Energy Group at BDSP Partnership.

Dr. Harries is member of the Energy Institute (MEI), has achieved his Chartership (CEnv) and lectures on sustainable design and renewable energy at the Architectural Association.

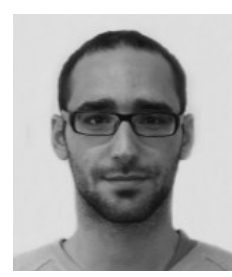

Ioannis Rizos studied mechanical engineering in the Polytechnic University of Patras, Greece, specializing in the Energy and Sustainability sector. After graduation (2005), he was offered a scholarship to elaborate an MSc by research in Energy Systems and the Environment at the ESRU in Glasgow.

He joined BDSP's environmental and simulation team in 2007 and started working on environmental performance modelling of individual buildings and masterplans, providing scientific support for energy, comfort and other sustainability issues within BDSP.

Mr. Rizos is also involved in BDSP's research and knowledge transfer activities, by authoring and co-authoring research papers and press releases, participating in key worldwide conferences in the field of low energy passive and active building design (PLEA and IBPSA). 